\title{
MATERNAL INVESTMENT BY YELLOWSTONE PRONGHORN FOLLOWING WINTER HABITAT DETERIORATION
}

\author{
Kerey K. Barnowe-Meyer' ${ }^{1}$ P.J. White ${ }^{2}$, and John A. Byers ${ }^{3}$
}

\begin{abstract}
Spring and summer-autumn nutrition are the prime determinants of reproductive investment in most largeherbivore populations, though winter severity is known to affect reproductive rates in some situations. To evaluate the effects of a long-term decline in winter habitat quality, a diet shift away from sagebrush (Artemisia spp.) during winter, and differential habitat selection during spring-autumn on pronghorn (Antilocapra americana) reproduction, we assessed female and fawn condition, maternal investment, and early fawn survival in migrant and nonmigrant portions of the Yellowstone pronghorn population in Montana and Wyoming during 1999-2001. Mean female mass at capture in late winter (46.81 kg, SE = 0.66), pregnancy rate $(0.94, \mathrm{SE}=0.03)$, date of birthing (median $=1 \mathrm{June})$, litter size $(1.90, \mathrm{SE}=0.07)$, ratio of litter mass to maternal mass $(0.134, \mathrm{SE}=0.005)$, fawn mass at birth $(3.08 \mathrm{~kg}, \mathrm{SE}=0.07)$, and fawn survival to August $(0.15, \mathrm{SE}=0.04)$ were within the ranges reported for populations elsewhere, and birth dates were uncorrelated with female mass and indexed condition the preceding winter. However, fawn age at death (median $=7$ days) was correlated with indexed fawn condition at birth, and indexed fawn condition and age at death were significantly greater for migrants occupying higher-elevation interior areas during the summer than for nonmigrants occupying the winter range year-round. Winter habitat conditions did not appear to substantially limit reproductive rates in this population during the study period. Our data suggest that spring and possibly summer nutrition may be higher for migrants than for nonmigrants, resulting in higher perinatal mass in migrant fawns and reduced neonatal mortality.
\end{abstract}

RESUMEN.—La nutrición durante la primavera y durante el verano-otoño primaveral y veraniega-otoñal son losconstituye el principales determinante principals de la inversión reproductiva en la mayoría de poblaciones de herbívoros grandes, aunque la severidad del invierno afecta las tasas reproductivas en algunas situaciones. Para evaluar los efectos de un descenso de largo plazo en la calidad del hábitat invernal, de una dieta con menos artemisa (Artemisia spp.) durante el invierno, y de diferencias en la selección del hábitat durante primavera-otoño sobreen la reproducción del berrendo (Antilocapra americana), nosotros examinamos la condición de las hembras y cervatos, la inversión maternal y la supervivencia temprana de cervatos en grupos migratorios y no migratorios de la población de berrendos Yellowstone en Montana y Wyoming, EE.U.AU. durante 1999-2001. El peso promedio de las hembras al tiempo de captura a finales del invierno $(46.81 \mathrm{~kg}, \mathrm{DE}=0.66)$, la tasa de embarazo $(0.94, \mathrm{DE}=0.03)$, la fecha de parto (mediana $=1$ de junio), el tamaño de camadaría $(1.90, \mathrm{DE}=0.07)$, la proporción del peso de cría con respecto al peso maternal $(0.134$, $\mathrm{DE}=0.005)$, el peso del cervato al nacer $(3.08 \mathrm{~kg}, \mathrm{DE}=0.07)$ y la supervivencia de los cervatos hasta agosto $(0.15, \mathrm{DE}=$ 0.04) estuvieron entre dentro de los rangos intervalos reportados para poblaciones en otros lugares, y las fechas de parto no estuvieron correlacionadas con el peso de las hembras o con el índice de condición del invierno anterior. Sin embargo, la edad de los cervatos al morir (mediana $=7$ días) estuvo correlacionada con el índice de condición de los cervatos al nacer, y el índice de condición de los cervatos y la edad al morir fueron considerablemente más altos para los individuos migratorios en áreas altas del interior durante el verano que para individuos no migratorios que se quedan en el rango invernal todo el año. Las condiciones del hábitat en invierno no parecieron limitar las tasas reproductivas de forma sustancial en esta población durante el periodoperíodo del estudio. Nuestros datos sugieren que la nutrición durante la primavera y posiblemente el verano puede ser mejor para los individuos migratorios que para los no migratorios, dando como resultados el elevadomayor peso perinatal y la reducidamenor mortalidad neonatal entre los cervatos migratorios.

Spring and summer-autumn nutrition are the prime determinants of many aspects of reproduction in large herbivores (reviewed in Gaillard et al. 2000, Cook et al. 2004a, Parker et al. 2009), including conception rate (Cameron et al. 1993, Cook et al. 2001, Langvatn et al. 2004), parturition date (Rachlow and Bowyer 1991, Schwartz and Hundertmark 1993, Cook et al. 2004a, García et al. 2006), perinatal condition (Barboza and
Parker 2006, 2008), early neonatal development (Verme and Ozoga 1980a, 1980b, Cook et al. 1996, Weladji and Holand 2003), and survival to weaning (Kie and White 1985, Gaillard et al. 1997, Portier et al. 1998, Cook et al. 2004a, Lomas and Bender 2007). Although pronghorn (Antilocapra americana) exhibit the highest rate of maternal investment among ungulates (Robbins and Robbins 1979, Byers and Moodie 1990),

${ }^{1}$ Wildlife Division, Nez Perce Tribe, Box 365, Lapwai, ID 83540. E-mail: kkbarnowe-meyer@vandals.uidaho.edu
${ }^{2}$ National Park Service, Yellowstone National Park, WY 82190.

${ }^{3}$ Department of Biological Sciences, University of Idaho, Moscow, ID 83844-3051. 
few studies have examined the relationship between nonwinter nutrition and reproductive rates (Byers and Moodie 1990, Byers and Hogg 1995, Byers et al. 2005a, 2005b, Dunn and Byers 2008). Malnutrition of either the mother or fawn can predispose fawns to additional sources of mortality, particularly predation (Beale and Smith 1970, Linnell et al. 1995, Sams et al. 1996, Gaillard et al. 2000). Therefore, clarifying the links connecting habitat conditions in various seasons, physiological condition, and early fawn mortality is critically important to understanding the ecological and demographic dynamics of at-risk populations (Parker et al. 2009).

Habitat conditions on Yellowstone National Park's northern range have been the subject of much conservation attention and unresolved debate (National Research Council 2002). Yellowstone pronghorn face a severe risk of extirpation due, in part, to ongoing concerns regarding the extent and quality of winter range near Gardiner, Montana (National Research Council 2002). Recent evidence suggests that winter forage conditions are marginal (Boccadori et al. 2008) and may regulate the long-term dynamics of this isolated population (White et al. 2007a). Sagebrush (Artemisia spp.), an important component of the winter diet in most northern pronghorn populations (Yoakum 2004), has declined in density and productivity on the winter range (Murie 1940, Houston 1982, Singer and Norland 1994, Singer and Renkin 1995, Wambolt and Sherwood 1999), resulting in a shift to rabbitbrush (Chrysothamnus spp.) and greasewood (Sarcobatus vermiculatus) in pronghorn winter diet selection (Boccadori et al. 2008). Elsewhere, a lack of access to preferred woody forage, heavy or crusted snow, overbrowsing, and shrub trampling has been shown to contribute to substantial adult and yearling mortality and fetal resorption during severe winters (Martinka 1967, Compton 1970, McKenzie 1970, West 1970, Barrett 1982). Despite these concerns, basic data on female condition, reproductive rates, and early fawn survival in this population have not been assessed for several decades (O’Gara 1968).

Yellowstone pronghorn are partially migratory, with some individuals remaining on the winter range year-round and others migrating into higher-elevation areas of the park during summer (White et al. 2007b). Fawn recruitment in this population is low (Barnowe-Meyer et al. 2010), with coyotes (Canis latrans) preying heavily on pronghorn across age classes (Barnowe-Meyer et al. 2009). The influence of habitat conditions on early fawn condition and vulnerability in this population have not been fully assessed despite substantial variation in recruitment between migrant and nonmigrant segments of the population (Barnowe-Meyer et al. 2010). Females occupy the same range during the winter, so differential habitat selection during the spring and summer provides the opportunity to explore the potential influence of seasonal habitat selection on early fawn condition (Taylor and Norris 2007). Understanding the relative influence of winter and summer conditions on adult reproductive success and early fawn survival in Yellowstone pronghorn would significantly contribute to ongoing research, modeling, and habitat-restoration efforts aimed at maintaining the long-term viability of this population (National Research Council 2002, White and Garrott 2005, White et al. 2007a, 2007b, Boccadori et al. 2008, Barnowe-Meyer et al. 2009, 2010). To provide direction for future research on the mechanisms driving reproductive success in this population, we documented the condition of Yellowstone pronghorn females and fawns, female reproductive parameters (i.e., pregnancy rates, birthing dates, litter sizes, and prenatal investment), and the age at death and survival of fawns to August. We then assessed differences in key parameters between migrant and nonmigrant portions of the population.

\section{Study Area}

Yellowstone pronghorn inhabit various open portions of the approximately $1500-\mathrm{km}^{2}$ northern range of Yellowstone National Park and nearby areas of Montana, a moderate- and highelevation area of mixed grasslands, shrubsteppe, and coniferous forests (Fig. 1). Pronghorn activity in winter is restricted to the arid and windswept basin surrounding Gardiner, Montana, on the northwestern portion of the northern range, an area of approximately $30 \mathrm{~km}^{2}$ lying below $1900 \mathrm{~m}$ elevation (Barmore 1980). The habitat in this area is chiefly open grassland and shrubsteppe dominated by fringed sage (Artemisia frigida), big sagebrush (Artemisia tridentata), rabbitbrush (Chrysothamnus spp.), bluebunch wheatgrass (Pseudoroegneria spicata), Idaho fescue (Festuca idahoensis), prairie Junegrass (Koeleria macrantha), prickly pear cactus (Opuntia polyacantha), Sandberg bluegrass (Poa secunda), and greasewood (Sarcobatus vermiculatus). These areas are 


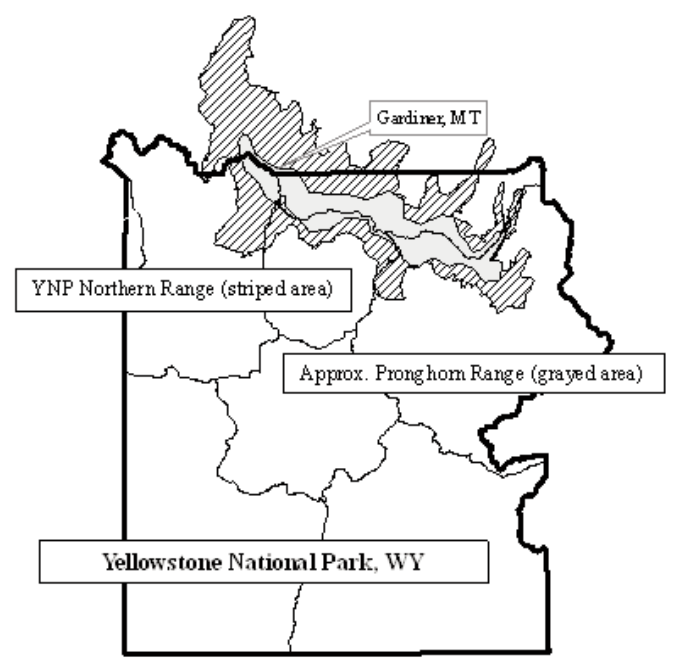

Fig. 1. Study area and approximate spatial extent of habitat use by pronghorn within Yellowstone National Park (YNP) and nearby areas of Montana.

interspersed with abandoned agricultural fields dominated by crested wheatgrass (Agropyron cristatum) and exotic forbs, active agricultural fields of alfalfa (Medicago sativa), and nonvegetated areas (Boccadori et al. 2008).

Between April and October each year, portions of the pronghorn population migrate to several interior summering areas along the Yellowstone and Lamar Rivers between 1800 and 2500 m elevation (White et al. 2007b). Vegetation in areas seasonally occupied by migrants is a mixture of grassland, shrubsteppe, and forest types with minor patches of riparian habitat. Dominant plant species in migrant areas include big sagebrush, rabbitbrush, bluebunch wheatgrass, Idaho fescue, and Sandberg bluegrass. Interspersed tree species include Engelmann spruce (Picea engelmannii), whitebark pine (Pinus albicaulis), lodgepole pine (Pinus contorta), quaking aspen (Populus tremuloides), and Douglas-fir (Pseudotsuga menziesii). Following parturition and several weeks of isolation in late spring, migrant females congregate in open habitat patches until autumn migration (White et al. 2007b). Nonmigrant individuals occupy the winter range year-round for foraging, birthing, and rearing young (White et al. 2007b).

Pronghorn share portions of both winter and summer ranges with populations of moose (Alces alces), bison (Bison bison), elk (Cervus canadensis), mule deer (Odocoileus hemionus), whitetailed deer (Odocoileus virginianus), mountain goats (Oreamnos americanus), and bighorn sheep (Ovis canadensis). Predators on Yellowstone's northern range include coyotes, gray wolves (Canis lupus), golden eagles (Aquila chrysaetos), wolverines (Gulo gulo), bobcats (Lynx rufus), cougars (Puma concolor), badgers (Taxidea taxus), grizzly bears (Ursus arctos), black bears (Ursus americanus), and red foxes (Vulpes vulpes; Barnowe-Meyer et al. 2009).

\section{Methods}

\section{Adult Capture and Monitoring}

We captured and radio-collared a total of 30 adult female pronghorn using helicopter-fired net guns during February 1999 and April 2000 (Barnowe-Meyer et al. 2009). Capture and handling were conducted in compliance with guidelines set forth by the American Society of Mammalogists (Gannon et al. 2007). Females were weighed and front-foot lengths were measured (Byers 1997a). We then relocated females using radiotelemetry equipment and visually observed individuals in order to obtain spatial and reproductive data. We determined migratory status using location data in the current birth year, with migrants classified as those leaving the winter range and crossing east beyond Mount Everts (White et al. 2007b). In the May-June birth season, we located radio-collared females 5-6 times weekly. We determined litter size per doe by observing birthing events and examining uteri of females that died during pregnancy, augmenting data with opportunistic birthing observations during 2004-2006 (as noted) to increase sample size. These opportunistic observations were made of instrumented females in subsequent years by following a monitoring protocol identical to that used throughout 1999-2001. For all other analyses, we utilized data gathered only during monitoring efforts conducted from 1999 through 2001. Population counts for 1999-2001 were steady at approximately 200 individuals (Keating 2002). In the autumns of 1998, 1999, and 2000, five depredation (harvest) tags were issued for private lands directly adjacent to the winter range (Keating 2002).

\section{Fawn Capture and Monitoring}

We approached on foot and manually restrained fawns within 3 days of birth (determined based on physical and behavioral characteristics; Byers 1997a, 1997b), documented the number 
of offspring (single fawn or twins), weighed each, and measured the length of the hind foot (Byers 1997a). Capture using our methods did not increase a fawn's risk of death (Byers 1997b). We calculated fawn mass at birth as

0.23 (mass at time of capture - days old at capture)

(Byers 1997a). We quantified prenatal investment in offspring prior to parturition (Byers and Moodie 1990, Pelabon et al. 1995) as

total litter mass / maternal mass,

calculated using maternal mass at time of capture and the sum of twin masses at birth (if known), or twice the mass of a single fawn when only one of 2 observed fawns could be captured (Byers and Hogg 1995). We did not calculate investment by those females accompanied by a single fawn only (O'Gara 2004b), because in those instances, we could not differentiate single births from those in which one of 2 fawns died prior to first detection. Maternal mass at parturition could not be derived, but the above index provided a basis for comparison with identically gathered data from other populations.

We attached solar-powered eartag transmitters with mortality sensors to 29 fawns from 1999 through 2001, including 26 fawns born to collared females and 3 captured opportunistically. We monitored signals from fawns daily to detect mortality events. When we failed to capture the fawn of a radio-collared female, we located that female daily and assessed fawn status $(n=41$ additional fawns; total $=70$ monitored fawns). We calculated each fawn's age at death based on fawn presence and suckling, the female's behavior (e.g., solitary or in a group; calm or wandering and unsuccessfully calling for a fawn), and size of the female's udder. Data on fawns lacking transmitters but otherwise known to be descended from instrumented females were gathered by near-daily visual monitoring until fawn death was detected or until 1 August, at which point fawns were considered weaned. Fawn survival to August (0/1) was determined based on instrumented fawn status and the observed presence of noninstrumented fawns in close maternal association with instrumented adult females.

\section{Analyses}

We compared full-population data with values documented for populations elsewhere and with O'Gara's (1968) previous observations of pronghorn in Yellowstone. For comparison of female and fawn condition between migrants and nonmigrants, indices of condition were quantified by deriving residuals from an ordinary least-squares regression of body mass at capture against limb length at capture. This provided indices of condition based additionally on the skeletal size of the individual. These indices were more accurate than those based on body mass alone (Schulte-Hostedde et al. 2005, Stevenson and Woods 2006). Though front limbs were measured on females and hind limbs were measured on fawns (Byers 1997a), these data were used solely to evaluate differences by migration within rather than between female and fawn groups. Using nonparametric rank correlation tests, we assessed associations between birth dates in the season following female capture and female mass, birth dates and indexed female condition, and indexed fawn condition and age at death. We compared female mass, indexed female condition, female pregnancy rate, fawn birth date, fawn mass, indexed fawn condition, fawn age at death, and fawn survival to August between migrant and nonmigrant groups by using nonparametric Mann-Whitney $U$ tests. Median age at death was used for analyses because of long tails in the data (Festa-Bianchet and Cote 2008), and it was also used for comparison with other studies. Nonparametric statistics were used because of sparse data and in an attempt to avoid violations of parametric assumptions. We conducted all analyses using PASW Statistics 17.0 (formerly and currently SPSS; IBM Corporation, Somers, NY). Graphs were produced using Stata 9.2 (StataCorp LC, College Station, TX).

\section{RESUlts}

\section{Female Condition and Reproductive Output}

We censored from analyses 2 females that died shortly after capture, one female and 2 fawns because the mother emigrated from the study area, and one female and one fawn because the mother switched from migrant to nonmigrant strategies between years (White et al. $2007 b$ ). One collared female did not exhibit signs of late-term pregnancy during our study and exhibited male pelage characteristics, suggesting she may have been infertile (O'Gara $2004 \mathrm{~b}$ ). This individual was censored from between-group pregnancy rate analyses but not 
TABLE 1. Female mass, reproductive rates, and fawn survival of Yellowstone pronghorn in Montana and Wyoming during 1999-2001, compared to values for populations elsewhere.

\begin{tabular}{|c|c|c|c|c|}
\hline \multirow[b]{2}{*}{ Variable } & \multicolumn{3}{|c|}{ Yellowstone, 1999-2001 } & \multirow{2}{*}{$\begin{array}{c}\text { Literature values } \\
\text { Range of means }\end{array}$} \\
\hline & $n$ & Mean & $\mathrm{SE}$ & \\
\hline Female mass (kg) & 26 & 46.81 & 0.66 & $41^{\mathrm{a}}-50^{\mathrm{b}}$ \\
\hline Pregnancy rate & 67 & 0.94 & 0.03 & $0.86^{\mathrm{c}}-0.97^{\mathrm{b}}$ \\
\hline Birth date & 42 & 1 Juned & 20 May-21 June & Late May to early Junef \\
\hline Litter sizeg & 21 & 1.90 & 0.07 & $1.85^{\mathrm{h}}-1.97^{\mathrm{i}}$ \\
\hline $\begin{array}{l}\text { Prenatal investment } \\
\text { (litter mass : maternal mass) }\end{array}$ & 22 & 0.134 & 0.005 & $0.130(\mathrm{SE}=0.005)^{\mathrm{j}}$ \\
\hline Fawn mass at birth $(\mathrm{kg})$ & 28 & 3.08 & 0.07 & $2.9-4.0^{\mathrm{k}}$ \\
\hline Age at death (days) & 56 & 7 & $1-32$ & 11 \\
\hline Fawn survival to August & 66 & 0.15 & 0.04 & $0.00-0.92^{1}$ \\
\hline $\begin{array}{l}\text { a'Hoover et al. } 1959 \\
\text { bMitchell } 1980 \\
\text { c'Canon et al. } 1997 \\
\text { d'Median } \\
\text { e'Range } \\
\text { fO'Gara 2004b } \\
\text { gData from 1999-2001 and 2004-2006 } \\
\text { h'Trainer et al. 1983 } \\
\text { iO'Gara } 1968 \\
\text { jJ. Byers, unpublished data from the National } \\
\text { k'Hansen 1955 } \\
\text { 'Jacques et al. } 2007\end{array}$ & ang & $(n=11), 1$ & & \\
\hline
\end{tabular}

the full-population summary. Eight other females either failed to conceive in some (but not all) years or resorbed developing fetuses prior to parturition (Table 1). We directly observed 20 different females during birthing or immediately thereafter from 1999 through 2006. Seventeen of these births were twins, 2 involved a single healthy fawn, and one involved a single stillborn fawn. We were unable to determine the presence or fate of a second fawn, so this last observation was excluded from analyses. We also examined the uterus of one female that died in winter and another that was killed by a coyote one day following parturition. The pregnant uterus contained twin fetuses, and the postpartum uterus showed both horns enlarged with a placental scar on each, indicative of past twinning (Table 1).

Female masses in late winter, pregnancy rates, birth dates, litter sizes, and prenatal investment were low to normal, and all fell within the ranges of values reported for other populations (Table 1). However, female mass and fetuses per doe were slightly lower than reported for this population during 1965-1967 (50 kg and 1.95 fetuses per doe, respectively; O'Gara 1968). Birth dates in the year following female capture were uncorrelated with female mass at time of capture (Kendall's 2-tailed $\tau=$ 0.057, $n=19, P=0.748)$ and indexed female condition (Kendall's 2-tailed $\tau=0.238, n=19$, $P=0.168)$.

\section{Fawn Condition and Survival}

Fawn birth masses and survival to August were normal relative to other populations (Table 1). Overall, 10 of 66 fawns with known fates (15.2\%) survived until August. We were able to assign accurate ages at death (within 2 days) to 56 fawns monitored from birth (100\% of those failing to survive until August). The median age at death was 7 days, and the distribution of age at death was bimodal (Fig. 2). Due to a high incidence of twinning, $73 \%$ of monitored fawns were siblings and thus did not represent truly independent data. However, fawn fates were different in $80 \%$ of sibling pairs in which at least one fawn survived, suggesting that a working assumption of independence in the data was reasonable. There was a positive correlation between fawn condition index and age at death (Kendall's one-tailed $\tau=0.596, n=14, P=$ 0.003; Fig. 3).

\section{Differences by Migratory Status}

Female masses exhibited substantial variability within migrant and nonmigrant groups (Table 2), and indexed female condition (regressed female mass : limb length residuals) did not differ between migrants and nonmigrants (Mann-Whitney $U$ test: $n=26, P=0.310$; Table 2). Similarly, pregnancy rates (MannWhitney $U$ test: $n=65, P=1.00)$ and birth dates (Mann-Whitney $U$ test: $n=42, P=$ 0.078 ) did not differ between groups (Table 2), 


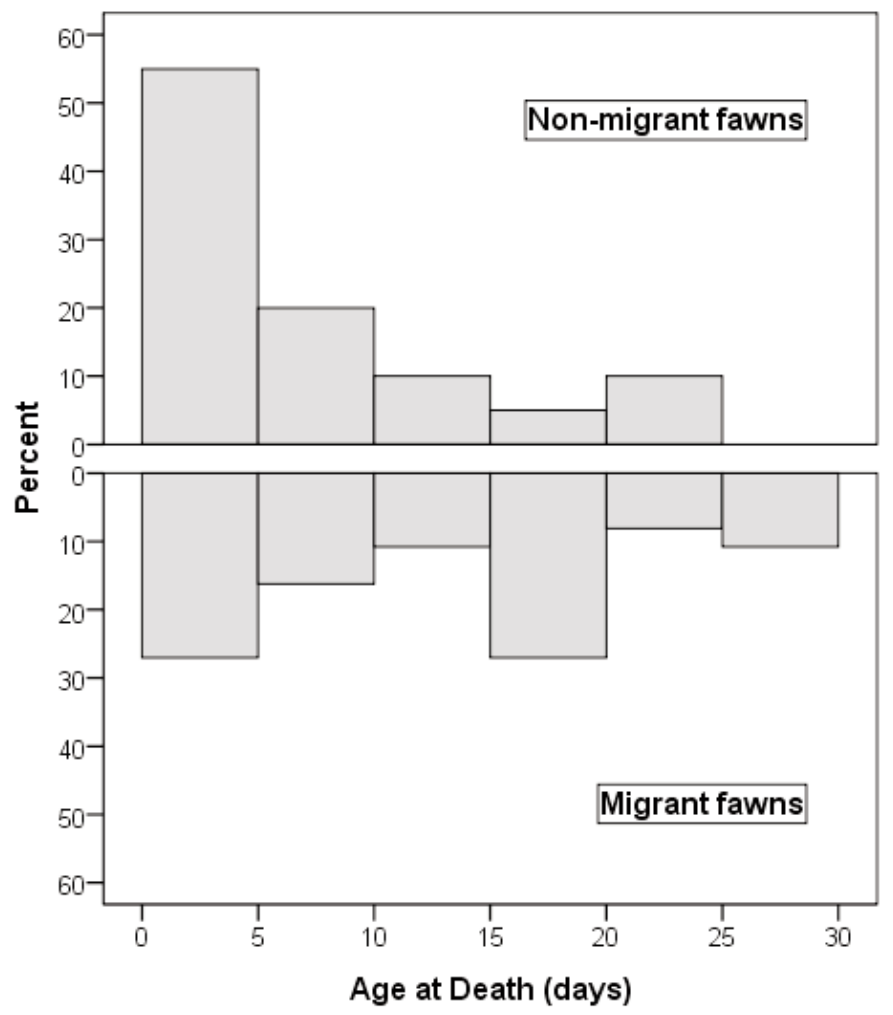

Fig. 2. Distribution of ages at death for 56 pronghorn fawns (19 nonmigrant, 37 migrant) born during 1999-2001 in Yellowstone National Park, Montana and Wyoming. Median age at death of nonmigrant and migrant fawns was 4 and 11 days, respectively.

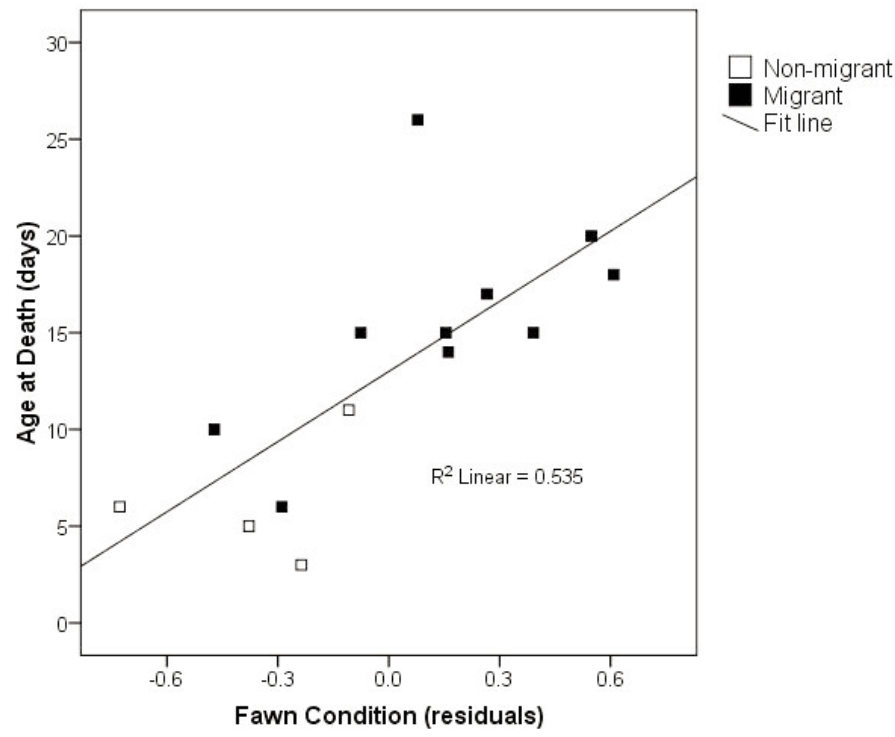

Fig. 3. Age at death versus condition index (unstandardized residuals from mass:hind-limb length regression) of 14 fawns of known age at death and condition born during 1999-2001 to nonmigrant and migrant female Yellowstone pronghorn in Montana and Wyoming. 
TABLE 2. Differences in select parameters by migratory strategy of Yellowstone pronghorn in Montana and Wyoming during 1999-2001.

\begin{tabular}{|c|c|c|c|c|c|c|c|c|c|}
\hline \multirow[b]{2}{*}{ Parameter } & \multicolumn{3}{|c|}{ Nonmigrants } & \multicolumn{3}{|c|}{ Migrants } & \multicolumn{3}{|c|}{ Mann-Whitney $U$ test } \\
\hline & $n$ & Mean & SE & $n$ & Mean & $\mathrm{SE}$ & $n$ & $Z$ & $P($ 2-tailed $)$ \\
\hline Female mass (kg) & 10 & 46.00 & 0.63 & 16 & 47.31 & 0.95 & 26 & -1.276 & 0.220 \\
\hline Female condition index ${ }^{a}$ & 10 & 0.085 & 0.246 & 16 & -0.033 & 0.136 & 27 & -1.028 & 0.310 \\
\hline Pregnancy rate & 19 & 0.95 & 0.05 & 46 & 0.93 & 0.04 & 65 & -0.191 & 1.000 \\
\hline Fawn birth date & 15 & 31 May & $2.6^{\mathrm{b}}$ & 27 & 2 June & $0.9^{b}$ & 42 & -1.763 & 0.078 \\
\hline Fawn mass (kg) & 10 & 2.97 & 0.13 & 18 & 3.14 & 0.08 & 28 & -1.776 & 0.076 \\
\hline Fawn condition index ${ }^{a}$ & 7 & -0.247 & 0.106 & 11 & 0.157 & 0.101 & 18 & -2.219 & 0.027 \\
\hline Age at death (days) & 19 & $4^{\mathrm{c}}$ & $1-21^{d}$ & 37 & $11^{\mathrm{c}}$ & $1-26^{\mathrm{d}}$ & 56 & -1.926 & 0.054 \\
\hline Fawn survival to August & 21 & 0.10 & 0.07 & 45 & 0.18 & 0.06 & 66 & - & $0.292^{\mathrm{e}}$ \\
\hline
\end{tabular}

despite an apparent 2-day delay in birthing by migrant females.

Indexed fawn condition was significantly higher for migrants than for nonmigrants (Mann-Whitney $U$ test: $n=18, P=0.027$ ); migrant fawn birth mass was, on average, $5.7 \%$ higher than nonmigrant fawn birth mass (Table 2). Migrant fawns had a median age at death 7 days greater than nonmigrant fawns among those failing to survive until August (MannWhitney $U$ test: $n=56, P=0.054$; Table 2). A difference in the distribution of fawn age at death by migratory strategy was apparent: nonmigrant fawn mortality was concentrated heavily in the days immediately following birth, while migrant fawn mortality was spread more evenly throughout the first 3 weeks of life (Fig. 2). Rates of survival to August of migrant and nonmigrant fawns were statistically similar (Fisher's exact test: $n=66, P=0.292$; Table 2) despite an apparent survival rate of migrant fawns that was $80 \%$ greater than that of nonmigrants (Table 2).

\section{Discussion}

\section{Female Condition}

We did not directly assess adult diet or nutrition in this study; our goal was to summarize reproductive rates in this population and provide direction for future work. Habitat impacts on large-herbivore reproductive output frequently manifest as variation in parturition date (Thomas 1982, Cameron et al. 1993, Cameron and Ver Hoef 1994, Keech et al. 2000, Cook et al. 2004a, Stewart et al. 2005) stemming from nutrition-related effects on conception date (Trainer 1971, Hudson et al. 1991, Cook et al. 2001, Cook et al. 2004a, Langvatn et al. 2004) or the prolonging of gestation when winter nutrition is low, thus ensuring offspring viability (Verme 1965, Rachlow and Bowyer 1991, Schwartz and Hundertmark 1993, Byers and Hogg 1995, Cook et al. 2004a, García et al. 2006, Festa-Bianchet and Cote 2008). However, we found no association between birth date and female condition at time of capture, nor did we find any difference in birth dates between migrants and nonmigrants in this population. Furthermore, for those females bearing twins, prenatal investment was high (Robbins and Robbins 1979, Byers and Moodie 1990). Contemporaneous data from pronghorn on the National Bison Range, where females are typically in excellent condition (Byers 1997a), indicated a similar level of maternal expenditure (for females carrying twins) for both populations. Pregnancy rates for Yellowstone pronghorn were relatively high. High pregnancy rates do not necessarily indicate a lack of nutrient stress (Verme and Ullrey 1984), as reproductive failure in early summer may allow females to more successfully conceive in autumn if summer nutrition is poor (Verme and Ullrey 1984, Cook et al. 2004a).

\section{Fawn Condition}

Fawns born to migrant females were in better indexed condition than those born to nonmigrant females, despite identical winter forage availability to females of both groups (White et al. 2007b). Though winter forage conditions determine the rate at which females deplete energy reserves (Mautz 1978, Cook et al. 2004a), this rate should have been identical for both migrants and nonmigrants (i.e., those with 
potentially differing nonwinter forage quality) and those that successfully and unsuccessfully weaned fawns the previous year (Cook et al. 2004a).

Perinatal condition is generally unaffected by maternal condition in the previous year and during the first 2 trimesters of gestation (Hudson et al. 1991, Schwartz and Hundertmark 1993, Byers and Hogg 1995, Cook et al. 2004a), except when conditions are so severe that fetal resorption or mummification results (Martinka 1967, Mitchell 1980, Barrett 1982, Byers et al. 2005a). Instead, numerous studies have linked perinatal condition to nutrition during late gestation (Murphy and Coates 1966, Holter and Hayes 1977, Verme and Ozoga 1980a, 1980b, Clutton-Brock et al. 1982, Adams et al. 1995, Cook et al. 1996, Martin and Parker 1997, O'Gara 2004a, Pettorelli et al. 2005, 2007, Barboza and Parker 2006, Barboza et al. 2009, Parker et al. 2009). Approximately $80 \%$ of pronghorn fetal mass development occurs in the final 50 days of gestation (Robbins and Robbins 1979), despite a decrease in female condition to a low in May (O'Gara 1968). Maternal nutritional status, and thus pre- and neonatal investment, is particularly sensitive to late winter through summer forage quality (Gaillard et al. 1997, Portier et al. 1998). In Yellowstone, spring and summer forage conditions likely vary between areas used by migrants and nonmigrants because of variation in plant phenology by elevation (Pettorelli et al. 2007) and increased spring and summer precipitation in migrant areas $(\bar{x}=$ 6.83 total inches April-July 1949-2010 at Tower Falls, Wyoming) compared to nonmigrant areas $(\bar{x}=4.78$ inches April-July 1956-2010 at Gardiner, Montana) (Western Regional Climate Center; www.wrcc.dri.edu). Migrant females arrive on their summer ranges by mid-April (White et al. 2007b), resulting in approximately 6 weeks of potentially divergent forage conditions for migrants and nonmigrants immediately preceding parturition.

Without additional data, a nutritional carryover from the previous summer by migrant females cannot be discounted. Females that failed to wean fawns the previous year might be expected to afford additional maternal investment in the subsequent year (Festa-Bianchet et al. 1998, Allaye Chan-McLeod et al. 1999). Summer drought, in conjunction with costly breeding behavior in autumn (Byers et al. $2005 \mathrm{~b}$ ), has been shown to affect gestation length and birthrate (but not birth mass) in pronghorn (Byers et al. 2005a, Dunn and Byers 2008). In elk, abundant high-quality forage during summer can entirely offset nutritional deficits in lactating (versus nonlactating) females by early autumn (Cook et al. 2004a), though this level of nutrition was not realized by Yellowstone elk during our study (Cook et al. 2004b). There were insufficient data to assess the influence of previous-year weaning success by female pronghorn on early fawn condition and survival. Females demonstrate general fidelity to migratory strategy in this population (White et al. 2007b), allowing potential carryover effects to be sustained within the migrant portion of the population.

Winter forage conditions can lead to low neonatal mass when nutrition is marginal and gestation cannot be prolonged (Kiltie 1982, Rachlow and Bowyer 1991). Body fat reserves are initially consumed during winter to prevent the loss of protein reserves critical for fetal growth (Murphy and Coates 1966, Torbit et al. 1985, Barboza and Parker 2006, 2008). Those individuals that conceive successfully, yet enter winter in relatively poor condition (Hobbs 1989), may be forced to metabolize body protein prematurely, resulting in low perinatal mass (Murphy and Coates 1966, Roffe 1993, Dwyer et al. 2003, Adams 2005, Barboza and Parker 2008). Poor winter forage quality on Yellowstone's winter range could accelerate protein losses for all females during early gestation, forcing the condition of nonmigrant females below a threshold necessary for the production of healthy offspring in late spring. No females appeared to be in such poor winter condition on the basis of the physiological metrics we examined (see also Dunbar 2002).

\section{Fawn Survival}

Spring forage conditions are known to affect early neonatal survival in many large-herbivore populations (Kie and White 1985, Gaillard et al. 1997, Portier et al. 1998, Lomas and Bender 2007). However, we did not find a significant difference between migrants and nonmigrants in the proportion of fawns surviving until August. Barnowe-Meyer et al. (2010) found a significant difference in survival between groups in this population on the basis of an expanded dataset containing data from 1999 to 2001 (this study) and data from fawns born in 2004-2006, suggesting a widening discrepancy in fawn 
survival rates between migrants and nonmigrants over time. The bimodal distribution of fawn age at death that we observed was characteristic of populations in which predation is the principal proximate cause of mortality (Barrett 1978, Von Gunten 1978, Corneli et al. 1984, Byers 1997a). The first peak corresponds to the days immediately following birth, and the second corresponds to the period in which fawns transition out of hiding and become more visible to predators (Fig. 2; Byers 1997a). The association we noted between perinatal condition and age at death suggests that high mortality of Yellowstone fawns (this study; Barnowe-Meyer et al. 2009) may be partly due to broader factors influencing the early vulnerability of fawns (Fairbanks 1993). Our preliminary data neither support nor disprove causal links connecting habitat conditions, maternal investment, or perinatal condition and eventual survival to weaning. Future work should investigate seasonal diet quality, habitat structure, and fawn condition at death within migrant and nonmigrant segments of this population.

Summary and Management Implications

Yellowstone pronghorn appear to be relatively healthy on the basis of the physiological and reproductive parameters we examined. Fawn mass at birth is higher for migrants inhabiting higher-elevation summer areas within the park than for nonmigrants remaining on the winter range year-round, suggesting that spring or summer nutrition may be better for migrants than for nonmigrants. Winter nutrition does not appear to drastically curtail reproductive investment in this population. However, improved winter nutrition could promote a higher baseline condition for females entering late gestation, improving the perinatal condition of nonmigrant fawns.

Our study coincided with a period of relatively mild winter weather and severe summer drought conditions (McMenamin et al. 2008), which likely amplified the influence of spring and summer habitat conditions and minimized the influence of winter conditions on reproductive rates in this population. A period of extreme summer drought followed by unexpectedly severe winter weather decimated the National Bison Range pronghorn population and caused reproductive collapse of that population in 2004 (Byers et al. 2005a, Dunn and Byers 2008). An unusually severe or prolonged winter in Yellowstone could lead to uniformly poor condition of fawns at birth or increased fetal resorption, particularly within the nonmigrant segment of the population. To improve forage conditions on the winter range for pronghorn, as well as for other species, the National Park Service has developed plans in conjunction with restoration experts to reestablish native vegetation in areas once tilled for agriculture and now supporting invasive nonnative species. Park personnel are also working with the USDA Forest Service, the state of Montana, private landowners, and conservation organizations to improve habitat and connectivity between the park and historic winter ranges to the north.

\section{ACKNOWLEDGMENTS}

This project received financial support from the Bernice Barbour Foundation, Montana State University, the National Park Service, the University of Idaho, and the Yellowstone Park Foundation. We thank J. Mack, W. Maples, M. Robinson, W. Clark, V. Boccadori, K. Pullen, H. Harris, C. Hernandez, L. Stinson, and K. Nittinger for data collection efforts. We also thank $\mathrm{K}$. Tonnessen and the Rocky Mountains Cooperative Ecosystem Studies Unit for facilitating funding agreements; Hawkins \& Powers Aviation, Helicopter Capture Services, Leading Edge Aviation; and Montana Aircraft for capture support, and 2 anonymous reviewers for providing constructive comments on a previous version of this manuscript.

\section{Literature Cited}

ADAms, L.G. 2005. Effects of maternal characteristics and climatic variation on birth masses of Alaskan caribou. Journal of Mammalogy 86:506-513.

Adams, L.G., FJ. Singer, And B.W. Dale. 1995. Caribou calf mortality in Denali National Park, Alaska. Journal of Wildlife Management 59:584-594.

Allaye Chan-McLeod, A.C., R.G. White, and D.E. RusSELL. 1999. Comparative body composition strategies of breeding and nonbreeding female caribou. Canadian Journal of Zoology 77:1901-1907.

Barboza, P.S., AND K.L. Parker. 2006. Body protein stores and isotopic indicators of $\mathrm{N}$ balance in female reindeer (Rangifer tarandus) during winter. Physiological and Biochemical Zoology 79:628-644.

2008. Allocating protein to reproduction in arctic reindeer and caribou. Physiological and Biochemical Zoology 81:835-855.

Barboza, P.S., K.L. Parker, and I.D. Hume. 2009. Integrative wildlife nutrition. Springer-Verlag, Berlin, Germany. 
Barmore, W.J. 1980. Population characteristics, distribution and habitat relationships of six ungulates in northern Yellowstone Park. Doctoral dissertation, Utah State University, Logan, UT.

Barnowe-Meyer, K.K., P.J. White, T.L. Davis, and J.A. BYERs. 2009. Predator-specific mortality of pronghorn on Yellowstone's northern range. Western North American Naturalist 69:186-194.

Barnowe-Meyer, K.K., P.J. White, T.L. Davis, D.W. Smith, R.L. Crabtree, and J.A. Byers. 2010. Influences of wolves and high-elevation dispersion on reproductive success of pronghorn (Antilocapra americana). Journal of Mammalogy 91:712-721.

BarretT, M.W. 1978. Pronghorn fawn mortality in Alberta. Proceedings of the 8th Biennial Pronghorn Antelope Workshop 8:429-444.

1982. Distribution, behavior, and mortality of pronghorns during a severe winter in Alberta, Canada. Journal of Wildlife Management 46:991-1002.

Beale, D.M., And A.D. Smith. 1970. Forage use, water consumption, and productivity of pronghorn antelope in western Utah. Journal of Wildlife Management 34: $570-582$.

Boccadori, S.J., P.J. White, R.A. GaRrotT, J.J. Borkowski, AND T.L. DAVIS. 2008. Yellowstone pronghorn alter resource selection after sagebrush decline. Journal of Mammalogy 89:1031-1040.

Byers, J.A. 1997a. American pronghorn: social adaptations and the ghosts of predators past. University of Chicago Press, Chicago, IL.

1997b. Mortality risk to young pronghorns from handling. Journal of Mammalogy 78:894-899.

Byers, J.A., A.A. Byers, And S.J. Dunn. 2005a. A dry summer diminishes mate search effort by pronghorn females: evidence for a significant cost of mate search. Ethology 112:74-80.

Byers, J.A., AND J.T. HoGG. 1995. Environmental effects on prenatal growth rate in pronghorn and bighorn: further evidence for energy constraint on sex-biased maternal expenditure. Behavioral Ecology 6:451-457.

Byers, J.A., AND J.D. MoODIE. 1990. Sex-specific maternal investment in pronghorn, and the question of a limit on differential provisioning in ungulates. Behavioral Ecology and Sociobiology 26:157-164.

Byers, J.A., P.A. Wiseman, L. Jones, and T.J. Roffe. 2005b. A large cost of female mate sampling in pronghorn. American Naturalist 166:661-668.

Cameron, R.D., W.T. Smith, S.G. Fancy, K.L. Gerhart, AND R.G. WHITE. 1993. Calving success of female caribou in relation to body weight. Canadian Journal of Zoology 71:480-486.

Cameron, R.D., And J.M. Ver Hoef. 1994. Predicting parturition rate of caribou from autumn body mass. Journal of Wildlife Management 58:674-679.

Canon, S.K., F.C. Bryant, K.N. Bretzlaff, and J.M. HELLMAN. 1997. Pronghorn pregnancy diagnosis using trans-rectal ultrasound. Wildlife Society Bulletin 25: 832-834.

Clutton-Brock, T.H., F.E. Guinness, and S.D. Albon. 1982. Red deer: behavior and ecology of two sexes. University of Chicago Press, Chicago, IL.

Compton, H.O. 1970. Southeastern Montana antelope population trends in relation to severe winters. Proceedings of the 4 th Biennial Pronghorn Antelope Workshop $4: 50-54$.

Cook, J.G., B.K. Johnson, R.C. Cook, R.A. Riggs, T. Delcurto, L.D. Bryant, and L.L. Irwin. 2004a.
Effects of summer-autumn nutrition and parturition date on reproduction and survival of elk. Wildlife Monographs 155:1-61.

Cook, J.G., L.J. Quinlan, L.L. Irwin, L.D. Bryant, R.A. Riggs, AND J.W. Thomas. 1996. Nutrition-growth relations of elk calves during late summer and fall. Journal of Wildlife Management 60:528-541.

CoOK, R.C., J.G. CoOK, AND L.D. МECH. 2004b. Nutritional condition of northern Yellowstone elk. Journal of Mammalogy 85:714-722.

Cook, R.C., D.L. Murray, J.G. CoOK, P. Zager, and S.L. MONFORT. 2001. Nutritional influences on breeding dynamics in elk. Canadian Journal of Zoology 79: 845-853.

Corneli, P.S., B. Von Gunten Moran, and B.W. O’Gara. 1984. Pronghorn fawn mortality on the National Bison Range. Proceedings of the 11th Biennial Pronghorn Antelope Workshop 11:41-48.

Dunbar, M.R. 2002. Physiological ecology of pronghorn of Yellowstone National Park, Wyoming. In: Proceedings of the Yellowstone Pronghorn Conservation Assessment Workshop. Yellowstone National Park, Mammoth Hot Springs, WY.

Dunn, S.J., AND J.A. BYERs. 2008. Determinants of survival and fecundity through a population bottleneck in pronghorn (Antilocapra americana). Journal of Mammalogy 89:1124-1129.

Dwyer, C.M., A.B. Lawrence, S.C. Bishop, and M. LEWIS. 2003. Ewe-lamb bonding behaviours at birth are affected by maternal undernutrition in pregnancy. British Journal of Nutrition 89:123-136.

FAIRBANKS, W.S. 1993. Birthdate, birthweight, and survival in pronghorn fawns. Journal of Mammalogy 74:129-135.

Festa-Bianchet, M., and S.D. Cote. 2008. Mountain goats: ecology, behavior, and conservation of an alpine ungulate. Island Press, Washington, DC.

Festa-Bianchet, M., J.-M. Gaillard, and J.T. Jorgenson. 1998. Mass- and density-dependent reproductive success and reproductive costs in a capital breeder. American Naturalist 152:367-379.

Gaillard, J.-M., J.-M. Boutin, D. Delorme, G. Van Laere, P. Duncan, and J.-D. Lebreton. 1997. Early survival in roe deer: causes and consequences of cohort variation in two contrasted populations. Oecologia 112:502-513.

Gaillard, J.-M., M. Festa-Bianchet, N.G. Yoccoz, A. LoIsOn, AND C. ToIgO. 2000. Temporal variation in fitness components and population dynamics of large herbivores. Annual Review of Ecology and Systematics 31:367-393.

Gannon, W.L., R.S. Sikes, and the Animal Care and Use Committee of the American Society of MammaloGISTS. 2007. Guidelines of the American Society of Mammalogists for the use of wild mammals in research. Journal of Mammalogy 88:809-823.

García, A.J., T. Landete-Castillejos, D. Carrión, E. GaspaR-LóPEZ, AND L. GaLLEGO. 2006. Compensatory extension of gestation length with advance of conception in red deer (Cervus elaphus). Journal of Experimental Zoology Part A: Comparative Experimental Biology 305A:55-61.

Hansen, E.L. 1955. Survival of pronghorn antelope in south-central Oregon during 1953 and 1954. Oregon State University, Corvallis, OR.

HobBs, N.T. 1989. Linking energy balance to survival in mule deer: development and test of a simulation model. Wildlife Monographs 101:3-39. 
Holter, J.B., AND H.H. HaYes. 1977. Growth in whitetailed deer fawns fed varying energy and constant protein. Journal of Wildlife Management 41:506-510.

Hoover, R.L., C.E. Till, and S. Ogilvie. 1959. The antelope of Colorado. Colorado Department of Game and Fish, Denver, CO.

Houston, D.B. 1982. The northern Yellowstone elk: ecology and management. Macmillan, New York, NY.

Hudson, J.R., H.M. KozaK, J.Z. Adamczewski, and C.D. OLSEN. 1991. Reproductive performance of farmed wapiti (Cervus elaphus nelsoni). Small Ruminant Research 4:19-28.

Jacques, C.N., J.A. Jenks, J.D. Sievers, D.E. Roddy, and FG. LINDZEY. 2007. Survival of pronghorns in western South Dakota. Journal of Wildlife Management 71: $737-743$.

KeAting, K. 2002. History of pronghorn population monitoring, research, and management in Yellowstone National Park. U.S. Geological Survey, Northern Rocky Mountain Science Center, Bozeman, MT

Keech, M.A., R.T. Bowyer, J.M.V. Hoef, R.D. Boertje, B.W. Dale, and T.R. Stephenson. 2000. Life-history consequences of maternal condition in Alaskan moose. Journal of Wildlife Management 64:450-462.

KIE, J.G., AND M. White. 1985. Population dynamics of white-tailed deer (Odocoileus virginianus) on the Welder Wildlife Refuge, Texas. Southwestern Naturalist 30:105-118.

KILTIE, R.A. 1982. Intraspecific variation in the mammalian gestation period. Journal of Mammalogy 63:646-652.

Langvatn, R., A. Mysterud, N.C. Stenseth, and N.G. YocCOZ. 2004. Timing and synchrony of ovulation in red deer constrained by short northern summers. American Naturalist 163:763-772.

Linnell, J.D.C., R. Aanes, And R. Andersen. 1995. Who killed Bambi? The role of predation in the neonata mortality of temperate ungulates. Wildlife Biology 1:209-223.

LOMAS, L.A., AND L.C. BENDER. 2007. Survival and causespecific mortality of neonatal mule deer fawns, northcentral New Mexico. Journal of Wildlife Management 71:884-894.

Martin, S.K., AND K.L. PARKER. 1997. Rates of growth and morphological dimensions of bottle-raised pronghorns. Journal of Mammalogy 78:23-30.

MarTinKA, C.J. 1967. Mortality of northern Montana pronghorns in a severe winter. Journal of Wildlife Management 31:159-164.

MauTZ, W.W. 1978. Sledding on a bushy hillside: the fat cycle in deer. Wildlife Society Bulletin 6:88-90.

McKenzIE, J.V. 1970. Two "killer winters," 1964-1965 and 1968-1969, in North Dakota. Proceedings of the 4th Biennial Pronghorn Antelope Workshop 4:36-40.

McMenamin, S.K., E.A. Hadly, and C.K. Wright. 2008. Climatic change and wetland desiccation cause amphibian decline in Yellowstone National Park. Proceedings of the National Academy of Sciences 105: 16988-16993.

MitcheLL, G.J. 1980. The pronghorn antelope in Alberta. S4S-OA2, Alberta Department of Energy and Natural Resources, Regina, Saskatchewan, Canada.

Murie, A. 1940. Ecology of the coyote in the Yellowstone. National Park Service Fauna Series Number 4, U.S. Government Printing Office, Washington, DC.

MuRPhy, D.A., AND J.A. COATES. 1966. Effects of dietary protein on deer. Transactions of the North American Wildlife and Natural Resources Conference 31:129-139.
National Research Council. 2002. Ecological dynamics on Yellowstone's northern range. National Academy Press, Washington, DC.

O'GARA, B.W. 1968. A study of the reproductive cycle of the female pronghorn. Doctoral dissertation, University of Montana, Missoula, MT.

2004a. Physical characteristics. Pages 109-144 in B.W. O’Gara and J.D. Yoakum, editors, Pronghorn: ecology and management. University Press of Colorado, Boulder, CO.

2004b. Reproduction. Pages 275-298 in B.W. O'Gara and J.D. Yoakum, editors, Pronghorn: ecology and management. University Press of Colorado, Boulder, CO.

Parker, K.L., P.S. Barboza, and M.P. Gillingham. 2009. Nutrition integrates environmental responses of ungulates. Functional Ecology 23:57-69.

Pelabon, C., J.-M. Gaillard, A. Loison, and C. Portier. 1995. Is sex-biased maternal care limited by total maternal expenditure in polygynous ungulates? Behavioral Ecology and Sociobiology 37:311-319.

Pettorelli, N., F. Pelletier, A. von Hardenberg, M. Festa-Bianchet, AND S.D. Côté. 2007. Early onset of vegetation growth vs. rapid green-up: impacts on juvenile mountain ungulates. Ecology 88:381-390.

Pettorelli, N., R.B. Weladji, O. Holand, A. Mysterud, H. Breie, and N.C. Stenseth. 2005. The relative role of winter and spring conditions: linking climate and landscape-scale plant phenology to alpine reindeer body mass. Biology Letters 1:24-26.

Portier, C., M. Festa-Bianchet, J.-M. Gaillard, J.T. JoRGENSON, AND N.G. YocCOZ. 1998. Effects of density and weather on survival of bighorn sheep lambs (Ovis canadensis). Journal of Zoology 245:271-278.

RACHLOW, J.L., AND R.T. BOWYER. 1991. Interannual variation in timing and synchrony of parturition in Dall's sheep. Journal of Mammalogy 72:487-492.

RobBins, C.T., and B.L. RobBins. 1979. Fetal and neonatal growth patterns and maternal reproductive effort in ungulates and subungulates. American Naturalist 114:101-116.

RoFFE, T.J. 1993. Perinatal mortality in caribou from the Porcupine herd, Alaska. Journal of Wildlife Diseases 29:295-303

Sams, M.G., R.L. Lochmiller, C.W. Qualls Jr., D.M. Leslie JR., AND M.E. PAYTon. 1996. Physiological correlates of neonatal mortality in an overpopulated herd of white-tailed deer. Journal of Mammalogy 77:179-190.

Schulte-Hostedde, A.I., B. Zinner, J.S. Millar, and G.J. HiCKLING. 2005. Restitution of mass-size residuals: validating body condition indices. Ecology 86: 155-163.

Schwartz, C.C., And K.J. Hundertmark. 1993. Reproductive characteristics of Alaskan moose. Journal of Wildlife Management 57:454-468.

SingER, F.J., AND J.E. NoRLAND. 1994. Niche relationships within a guild of ungulate species in Yellowstone National Park, Wyoming, following release from artificial controls. Canadian Journal of Zoology 72:1383-1394.

SINGER, FJ., AND R.A. RENKIN. 1995. Effects of browsing by native ungulates on the shrubs in big sagebrush communities in Yellowstone National Park. Great Basin Naturalist 55:201-212

Stevenson, R.D., And W.A. Woods JR. 2006. Condition indices for conservation: new uses for evolving tools. Integrative and Comparative Biology 46:1169-1190. 
Stewart, K.M., R.T. Bowyer, B.L. Dick, B.K. Johnson, AND J.G. KIE. 2005. Density-dependent effects on physical condition and reproduction in North American elk: an experimental test. Population Ecology 143: 85-93.

TAYLOR, C.M., AND D.R. NORRIS. 2007. Predicting conditions for migration: effects of density dependence and habitat quality. Biology Letters 3:280-283.

Thomas, D.C. 1982. The relationship between fertility and fat reserves of Peary caribou. Canadian Journal of Zoology 60:597-602.

Torbit, S.C., L.H. Carpenter, D.M. SWIFT, AND A.W. ALLDREDGE. 1985. Differential loss of fat and protein by mule deer during winter. Journal of Wildlife Management 49:80-85.

Trainer, C.E. 1971. The relationship of physical condition and fertility of female Roosevelt elk (Cervus canadensis roosevelti) in Oregon. Master's thesis, Oregon State University, Corvallis, OR

Trainer, C.E., M.J. Willis, G.P. Keister Jr., and D.P. SHEEHY. 1983. Fawn mortality and habitat use among pronghorn during spring and summer in southeast Oregon, 1981-1982. Wildlife Research Report No. 12, Oregon Department of Fish and Wildlife, Portland, OR.

VERME, L.J. 1965. Reproduction studies on penned whitetailed deer. Journal of Wildlife Management 29:74-79.

Verme, L.J., AND J.J. Ozoga. 1980a. Effects of diet on growth and lipogenesis in deer fawns. Journal of Wildlife Management 44:315-324.

1980b. Influence of protein-energy intake on deer fawns in autumn. Journal of Wildlife Management 44:305-314.

VERME, L.J., AND D.E. UlLREY. 1984. Physiology and nutrition. Pages 91-118 in L.K. Halls, editor, White-tailed deer: ecology and management. Stackpole Books, Harrisburg, PA.

Von Gunten, B.L. 1978. Pronghorn fawn mortality on the National Bison Range. Proceedings of the 8th Biennial Pronghorn Antelope Workshop 8:394-416.

Wambolt, C.L., AND H.W. Sherwood. 1999. Sagebrush response to ungulate browsing in Yellowstone. Journal of Range Management 52:363-369.

Weladji, R.B., and O. Holand. 2003. Global climate change and reindeer: effects of winter weather on the autumn weight and growth of calves. Oecologia 136: 317-323.

WEST, D.E. 1970. Effects of prolonged deep snow and cold winters on pronghorn mortality and reproduction in South Dakota. Proceedings of the 4th Biennial Pronghorn Antelope Workshop 4:41-49.

White, P.J., J.E. Bruggeman, and R.A. Garrott. 2007a. Irruptive population dynamics in Yellowstone pronghorn. Ecological Applications 17:1598-1606.

White, P.J., T.L. Davis, K.K. Barnowe-Meyer, R.L. Crabtree, and R.A. GaRRott. 2007b. Partial migration and philopatry of Yellowstone pronghorn. Biological Conservation 135:502-510.

White, P.J., AND R.A. GARRotT. 2005. Yellowstone’s ungulates after wolves - expectations, realizations, and predictions. Biological Conservation 125:141-152.

YOAKUM, J.D. 2004. Foraging ecology, diet studies and nutrient values. Pages 447-502 in B.W. O'Gara and J.D. Yoakum, editors, Pronghorn: ecology and management. University Press of Colorado, Boulder, CO.

Received 6 March 2010 Accepted 14 February 2011 